\section{MIND AND VOICE}

Brain Function, Vol. 3

Edited by Edward C. Carterette. (Proceedings of the Third Conference, Nov. 1963-Speech, Language and Communication. UCLA Forum in Medical Sciences, No. 4.) Pp. xiii +279 . (Berkeley and Los Angeles: University of California Press; London: Cambridge University Press, 1966.) 96s. net.

IN the past decade scientific publication has increasingly tended, at least in the more progressive fields, to occur as a by-product of those occasions in Tokyo, Miami or Florence when thirty-two or -three are gathered together in the name of multi-disciplinary enterprise. Whether this formula for collaborative progress is working itself to death or not, the outcome in cold print is not always optimal as a cerebral stimulant for the reader. Redun. dancy, cross-purposes, and displays of throw-away erudition may all induce somnolence.

This volume of contributions and discussions has the faults of its kind, but includes as well some rewarding elements. Geschwind's challenging little essay on Wernicke's place in the history of aphasia study is an admirable corrective to the contemporary over-swing in favour of the English school of neurologists. It perhaps deserves a wider circulation among potentially interested readers than it is likely to get in its present company. Roberts's views on the central brain mechanisms of speech have directness and simplicity befitting his surgical distinction; one of the briefest papers, it provoked one of the longest discussions. Lenneberg's essay on the anatomical and physiological concomitants of speech and development can scarcely fail to whet the reader's appetite for his forthcoming book. Jakobson gives a useful survey of recent work relevant to his now well known two linguistic types of aphasia. Speech disorders in childhood, especially those associated with brain damage, have had far too little intensive study. Ajuriaguerra's suggestive contribution may do something to remedy this. The value of quantitative techniques deriving from experimental psychology for aphasia research is not as widely appreciated as it should be, and Wepman and Jones's explicit example of how they can be woven into the individual case study could be thought over with profit by those clinicians who are hesitant in making use of them. There are contribu. tions by Lamb (a linguist), Osgood (a psychologist), Hoijer (an anthropologist), and Ferguson (an applied linguist) from diverse angles which produced varied reactions, to judge by the ensuing discussions.

The book as a whole serves to emphasize the fact that, as a result of a convergence of interests and the consequent availability of a variety of technical and methodological resources, there is now a favourable opportunity for real progress in understanding the nature and mechanisms of speech, language and communication. At present the atmosphere is multi-lingual rather than polyglot. A common tongue cannot be artificially contrived, but may well develop as solid results begin to emerge.

\section{R. C. Oldfiemd}

\section{OBITUARIES}

\section{Academician Vladimir Sukatchev}

THE prominent biologist and geographer Professor V. Sukatchev died on February 9 in Moscow. He was born in 1880 in a village in the Kharkov region and in 1902 graduated from the Petersburg Institute of Forestry.

By detailed examination, mainly of forests and marshes, as well as steppes and meadows, Sukatchev developed his own methods in plant ecology during the first quarter of the present century. His book Plant Communities was first published at this time. He had already established some of the principles of present day European phytosociology - the term itself was recommended by him in 1910. Sukatchev's principles for the distribution of plant communities and their grouping into ecological and phytocoenic series are well known. Several generalizations concerning the dynamics of vegetation and forest structures are due to him. He is considered one of the founders of the biological trend in the study of marshes in the Soviet Union. His book Marshes, their Formation and Characteristics was published several times. For many years he studied the Quaternary fossil flora, and on the basis of this research, as well as on spore and pollen analysis, he made important deductions alcout the palaeogeography of the interglacial stages in Eastern Europe and Western Siberia.

After 1914 Sukatchev worked on experimental phytocoenology. He put into practice for the first time original methods for investigating competition between species, and between the biotypes and ecotypes within the species. Sukatchev worked persistently to improve methods of field research. His best known publication is the Guide to the Research of Forest Types. Regional examination of vegetation was made by him or under his supervision in the Russian plateau, in Siberia and the Urals, in the Crimea, the Caucasus and in Middle Asia. From his travels came dozens of publications--a great contribution to botanical geography.

At the end of the nineteen-thirties Sukatchev formed an original conception of the complex study of the natural environment; it formed the basis of the scientific trend which he called biocoenology. He devoted the last twenty years of his life to working out a theoretical basis for biocoenology and to a complex study of forest biocoenoses. The book Programme and Methods of Biogeocoenological Investigations was published shortly before his death.

At the Institute of Forestry Sukatchev trained many prominent foresters and typologists. At the beginning of the present century he supported women's higher education in agronomy and taught botany and ecology in the Stebut Institute. In 1925 he organized a chair of geobotany at the Leningrad University and was head of the Leningrad geobotanical school.

Sukatchev held many posts: from 1912 he worked at the Academy of Sciences; he started as a junior botanist, became a corresponding member in 1920, AcademicianOrdinaire in 1943, director of the Forest Institute in 1944 and finally deputy to the Academician Secretary of the General Biological Branch of the Academy of Sciences of the Soviet Union. For many years he was active in botanical life. He was constitutor-member in 1915, and president from 1946, of the Botanical Society of the Soviet Union. He was also president of the Moscow Society of Naturalists and an honorary member of the Geographical Society of the Soviet Union. He served as the head of the Academy of Sciences' Commission for the study of the Quaternary period and he was the chief editor of the Botanical Magazine for many years.

Vladimir Sukatchev was an untiring worker, a passionate naturalist, brought up on the ideas of Charles Darwin and Vassily Dokutchaev. He fought selflessly for the purity of moral principles in science and life; was very popular and sincerely respected. Sukatchev received many scientific and state decorations. In the Soviet Union he was awarded the highest honorary title of a Hero of Socialist Labour.

V. SотснаVA

\section{Dr. J. K. Sen}

Dr. Jitendra Kumar Sen, who died at his home in the Indian Botanic Garden, Calcutta, on December 12 aged 45 , was a distinguished palaeobotanist.

He obtained an honours degree and a masters degree from the University of Calcutta, where he attended the 
University College of Science. From 1940 he was a lecturer in the Department of Botany at the University of Calcutta and during this time obtained his D.Phil. degree. In 1961 he became the last of a line of superintendents of the Indian Botanic Garden which began with Robert Kyd in 1787. When this institution was transferred to the Government of India in 1963, Sen became deputy director of the Botanical Survey of India.

Sen was the first to apply the palynology of coal, oil and petroleum to stratigraphical geology in India. $\mathrm{He}$ also described the reproductive organs of the fern Glos. sopteris, which gave valuable information about the evolutionary position of the plant. By means of X-ray diffraction he showed the changes which take place in the cell walls of wood during its degradation.

Sen was a fellow of the Geological and Linnean Societies of London, and of the Geological and Palaeontological Societies of India. He was a vice-president of the Botanical Society of Bengal.

\section{J. Cooper}

ViCTor JAMes CoOPER, who died on March 6, was deputy director of product planning for the Marconi Company, and was a distinguished television and radio engineer.

Cooper was born in 1911 and was educated at Sir Walter St. Johns School and City and Guilds College, University of London. In 1936 he joined the Marconi Company, to work on the development of MF and $\mathrm{HF}$ transmitters. After radar research during the Second World War he became involved in television work, which included responsibility for the design and development of the high level modulator for the B.B.C. Holme Moss transmitter. This modulator was colour compatible and the first of its kind in Britain; this was at a time when American colour systems were also first beginning. Cooper was later in charge of the design of the Marconi colour camera, which was the first one to be supplied to the B.B.C. in the early days of colour experimentation. As chief television engineer, in 1959, he took charge of work on closed circuit television when it was still at the pioneering stage.

At the time of his death Cooper was a member of the technical sub-committee of the Postmaster General's Television Advisory Committee. $\mathrm{He}$ had also been chairman of the Television Society, and in 1955, led the British delegation to the International Electrotechnical Commission Conference. He died with an international reputation in the world of television and radio.

\section{University News:}

Aston in Birmingham

Professor J. E. FLOOD, at present professor of light current electrical engineering in the university, has been appointed head of the Department of Electrical Engineering.

Massachusetts Institute of Technology

Dr. John M. Buchanan, head of the division of biochemistry of the Department of Biology, has been appointed the first John and Dorothy Wilson professor at the Institute.

\section{Victoria University of Wellington}

Dr. F. F. Evison, formerly director of the Geophysics Division of the Department of Scientific and Industrial Research, Wellington, has been appointed to the newly established chair of geophysies.

\section{Appointments}

Four new members of the United States Science Advisory Committee have been appointed for a term of four years until the end of 1970. They are Dr. Michael Ference (Ford Motor Company), Dr. James C. Fletcher (Univer- sity of Utah), Dr. Lewis Thomas (New York University School of Medicine), and Dr. F. H. Westheimer (Harvard University).

\section{Announcements}

Mr. J. S. McDonnell, chairman and chief executive officer of the McDonnell Aireraft Corporation of St. Louis, Missouri, has been awarded the second Founders' Medal of the U.S. National Academy of Engineering.

Dr. A. KeLly, lecturer in metallurgy in the University of Cambridge, has been awarded the William Hopkins Prize of the Cambridge Philosophical Society for his contributions to the study of the role of fibres and precipitates in strengthening materials, and for his monograph on strong solids, published in 1966.

Professor Kenneth N. Ogle, professor of physiological optics at the Mayo Graduate School of Medicine, has been awarded the Optical Society of America's Edgar D. Tillyer Medal, and Dr. George A. Morton, director of the Conversion Devices Laboratory at R.C.A. Laboratories, Princeton, New Jersey, has been awarded the society's David Richardson Medal.

Dr. Richard M. Krein of the New York Botanical Garden is compiling a Sourcebook of Methods in Develop. mental Botany intended to help with the introduction of developmental botany into the curriculum. Dr. Klein and his colleagues on a committee of the Botanical Society of America solicit ideas and techniques which have been shown "to work and to be stimulating to students".

AN organization known as the Peripheral Circulation Group has been established in Glasgow to arrange for informal discussions of matters concerning peripheral circulation, microcirculation, and the relationship between flow of fluids and the function of local tissues. Further details can be had from Dr. I. A. Sewell, the Royal Infirmary, Glasgow, C.4.

\section{Meetings}

Spring Menting of the Western States Section of the Combustion Institute, April 24-25, University of California (Western States Section/The Combustion Institute, c/o Dr. Forman A. Williams, 5230 Urey Hall, University of California, San Diego, La Jolla, California 92037).

Corrigendum. In the article entitled "Phase Dependent Changes of Circadian Frequency after Light Steps" by Michael Lohmann (Nature, 213, 196; 1967), lines 11-14 should have read: ". . . that is, a continuous action of the light intensity on a frequeney determining parameter of the biological oscillation. The timing of the transition from one light intensity to another in this interpretation has no effect on the subsequent frequency,1," The legend to Fig. 1 should have read: “. . . from a lower to a higher intensity (onset of activity $=0^{\circ} / 360^{\circ}$ ). Black circles indicate light steps from 0.01 to 2 lux, open circles 2 to 100 lux. Means with standard error refer to data within $90^{\circ}$ segments of the abscissa. Dashed line equals the overall mean." The final sentence of the fifth paragraph should have read: "No dependence of the after-effects on phase has been reported".

Corrigendum. In the article by B. G. Forget and S. M. Weissman entitled "Low Molecular Weight RNA Components from $K B$ Cells" (Nature, 213, 878; 1967), para. 6, line 14, 'Cellogel' should read 'Sepraphore No. 3, and line 15, 'Sepraphore No. 3' should be 'Cellogel'; para. 12 , line 12 should read "spots 39 and 62 " and line 15 should be " 2 ' and 4 " ; in para. 13 , line 22 , "and 24 " should be omitted. The following corrections should also be made to Table 2: Spot No. 23, component $C$, "O"; No. 29, VA-RNA, "Tr"; No. 54, "(G, A) GGU"; No. 80, "A (A, G) AGU”; N'o. 108, "G (G, A) AGU”. 